\title{
Chemometric evaluation of nitrate contamination in the groundwater of a hard rock area in Dharapuram, south India
}

\author{
P. J. Sajil Kumar · P. Jegathambal • \\ E. J. James
}

Received: 9 September 2013/ Accepted: 20 January 2014/Published online: 11 February 2014

(C) The Author(s) 2014. This article is published with open access at Springerlink.com

\begin{abstract}
This paper presents the results of investigations on groundwater nitrate contamination in the Dharapuram area of Tamil Nadu in south India as a primary step to initiate denitrification. Groundwater samples were collected from 26 selected locations during the pre-monsoon season in July 2010 and analysed for nitrate and other water quality parameters. Two important water types were identified, viz. $\mathrm{Ca}-\mathrm{Na}-\mathrm{HCO}_{3}$ and mixed $\mathrm{Ca}-\mathrm{Mg}-\mathrm{Cl}$. It is found that the majority of samples possess high nitrate concentration; $57 \%$ of samples exceeded the permissible limit of Indian $(45 \mathrm{mg} / \mathrm{L})$ and $\mathrm{WHO}(50 \mathrm{mg} / \mathrm{L})$ drinking water standard. Spatial distribution map of $\mathrm{NO}_{3}$ suggested that major contamination was observed in the $\mathrm{SW}$ and $\mathrm{NW}$ parts of the study area. This result was in agreement with the corresponding land-use pattern in this study area. Denitrification process at greater depths was evident from the negative correlation between $\mathrm{NO}_{3}$ and well depth. The sources and controlling factors of high nitrate were investigated using cross plots of $\mathrm{NO}_{3}$ with other selected hydrochemical parameters. Positive correlation for $\mathrm{NO}_{3}$ was observed with $\mathrm{EC}, \mathrm{K}, \mathrm{Cl}$ and $\mathrm{SO}_{4}$. This analysis was capable of differentiating the various sources of nitrate in groundwater. The major sources of nitrate contamination are identified as areas of high fertilizer application, sewages and animal waste dumping yards. Regulation of these pollutant sources with appropriate and cost-effective
\end{abstract}

P. J. Sajil Kumar $(\bowtie)$ · P. Jegathambal · E. J. James Water Institute, Karunya University, Karunya Nagar, Coimbatore 641114, India

e-mail: pjsajil@googlemail.com; pjsajil@gmail.com

Present Address:

P. J. Sajil Kumar

Brandenburgische Technische Universität, 03046 Cottbus, Germany denitrification process can restore the water quality in this area.

Keywords Groundwater - Nitrate contamination . Dharapuram · South India

\section{Introduction}

Groundwater is a readily available drinking water source for many parts of India. Due to various factors including climate change, the semi-arid zones of the country are highly influenced by nitrate concentration. This contamination is largely controlled by the application of nitrogenous fertilizers and manures, wastewater disposal, oxidation of nitrogenous human and animal excreta (WHO 2011). Studies by various researchers suggest that factors such as well depth, soil type, precipitation, farming practices and geochemical reducing environments are largely controlling the occurrence of nitrate in groundwater (Townsend and Young 2000; Hallberg 1989; Spalding and Exner 1993). Nitrate is seldom present in geological formations and therefore contamination due to nitrate is mainly attributed to anthropogenic sources such as sewages and fertilizers. Microbial nitrification is the natural origin of nitrate. Through this process, ammonia is converted into nitrite and then nitrite to nitrate by the nitrosomonas genus and nitrobacter genus bacteria, respectively (equation 1 and 2). The reactions that occur during the nitrogen cycle are:

$2 \mathrm{NH}_{4}+4 \mathrm{O}_{2}=2 \mathrm{NO}_{2}+4 \mathrm{H}_{2} \mathrm{O}$

$2 \mathrm{NO}_{2}+\mathrm{O}_{2}=2 \mathrm{NO}_{3}$

Nitrification is mainly controlled by $\mathrm{pH}$, temperature, concentration of ammonium and the microbial population. 
Since nitrate has more stable oxidation state than nitrite, it is less absorbed by the aquifer matrix. Due to its mobility, it can travel long distances and pollute the groundwater easily (Assaf and Saadeh 2009). Nitrate contamination is predominant in the states of India such as Punjab, West Bengal, Andhra Pradesh, Tamil Nadu and Delhi, which have a major incidence of nitrate contamination.

Humans, animals and ecology are equally affected by nitrate contamination in water. The human health risk associated with consumption of water containing nitrate is mainly due to the reduction of nitrate to nitrite in the human gut. Serious health problems have been reported in humans due to high consumption of nitrate. Nitrate is a predecessor to the development of the genotoxic $N$-nitroso compounds (NOC), which are known animal carcinogens (Ward et al. 2005). A high level of nitrate in the human body may lead to methaemoglobinaemia, a blood disorder in which an abnormal amount of methemoglobin is produced, preventing the oxygen distribution in the body. Young infants, pregnant women and elderly people are more susceptible to this disease than adults. This altered condition in oxygen transport causes infant cyanosis or blue baby syndrome (Comly 1987). Other possible health impacts can be hypertension, increased infant mortality and stomach cancer. Studies on animals in the laboratory have not indicated that nitrate or nitrite is directly carcinogenic, but it may react in the stomach with food containing secondary amines to produce $N$-nitroso compounds which are known to be carcinogenic in animals (LWRRDC 1999). At greater depths, denitrification is significant and depletes $\mathrm{NO}_{3}$. Since the important sources of nitrate contamination are surface water based, groundwater-surface water interaction is the major process that can elevate the concentration of $\mathrm{NO}_{3}$ in groundwater. High nitrate in groundwater results in eutrophication and algal blooms in the surface water sources and it is considered as one of the largest threats to aquatic ecology.

Groundwater contamination due to nitrate was studied by various researchers (Rao 2006; Benson et al. 2007; Murgulet and Tick 2009; Melo et al. 2011; Mishima et al. 2011; Maruyama et al. 2011; Cheong et al. 2011). The effect of land-use changes and irrigation water resource on the nitrate contamination in shallow groundwater in Huantai was examined by Chen et al. (2010). They have reported that under the same land-use condition, irrigation with sewage, or well and sewage by turns, would enormously add nitrate to the groundwater. A positive correlation between the groundwater nitrate concentration and the percentage of cropland was observed in Austria (Wick et al. 2012). Furthermore, they have proved that higher average temperatures result in lower nitrate concentration, possibly due to increased evapotranspiration. Groundwater nitrate contamination in the city of Konya, Turkey, was assessed using
GIS techniques in connection with hydrogeochemical analysis. This study showed that increasing depth has no correlation with nitrate contamination (Nas and Berktay 2006). In an Indian context, an elevated concentration ranging from 5 to $300 \mathrm{mg} / \mathrm{L}$ was reported from Gangapur City, Rajasthan, posing serious health impacts (Agarwal 2012). A study by Mondal et al. (2008) in Krishna delta in southern India indicates that groundwater of north Krishna delta is more polluted with nitrate than the southern part. The possible sources for the high nitrate level in groundwater were identified as excessive utilization of nitrogenous fertilizers for agricultural purposes.

Dharapuram represents a part of the semi-arid hard, rock terrains in Tamil Nadu with intensive agricultural practices. The present study has been formulated with an objective of determining the level and distribution of nitrate in the groundwater with a special emphasis on the natural and anthropogenic controls. This is a first study of this kind, conducted for delimiting the contaminated areas to initiate the denitrification processes.

\section{Materials and methods}

\section{Study area}

Dharapuram is located in the semi-arid zone in Tamil Nadu State of India (Fig. 1). The temperature of this region ranges from 20 to $40{ }^{\circ} \mathrm{C}$. The north-east monsoon mainly contributes to the rainfall in the district. The average rainfall of the study area is $600 \mathrm{~mm}$. The study area consists of mainly high-grade metamorphic rocks. These hard gneissic rocks are underlined by recent alluvium in certain pockets. The most common rock type of the area is hornblende-biotite gneisses (CGWB 2008; Arumugam and Elangovan 2009). A detailed map of the geology of Dharapuram is shown in Fig. 2. Soil types of the study area can be classified into fine, fine loamy, loamy skeletal and clayey loamy.

The aquifer systems in the district predominantly consist of weathered, fissured and fractured crystalline rocks and recent alluvial deposits in very few locations. In the crystalline rocks, groundwater occurs under phreatic conditions in the weathered mantle and under semi-confined conditions in the fractured zones (CGWB 2008). The weathered mantle of these hard rocks has a maximum thickness of 1-30 m. In large-diameter wells in crystalline formation, the drawdown ranged from 10.04 to $227.5 \mathrm{lpm}$ and transmissivity was $11.96-420 \mathrm{~m}^{2} /$ day. The water supply to a large portion of the study area is derived from deep dug wells, reaching $35-45 \mathrm{~m}$ below the ground level, demanding a high financial capital. The major portion of groundwater is extracted for irrigation. As an agrarian 
Fig. 1 Location map of study area showing sampling wells
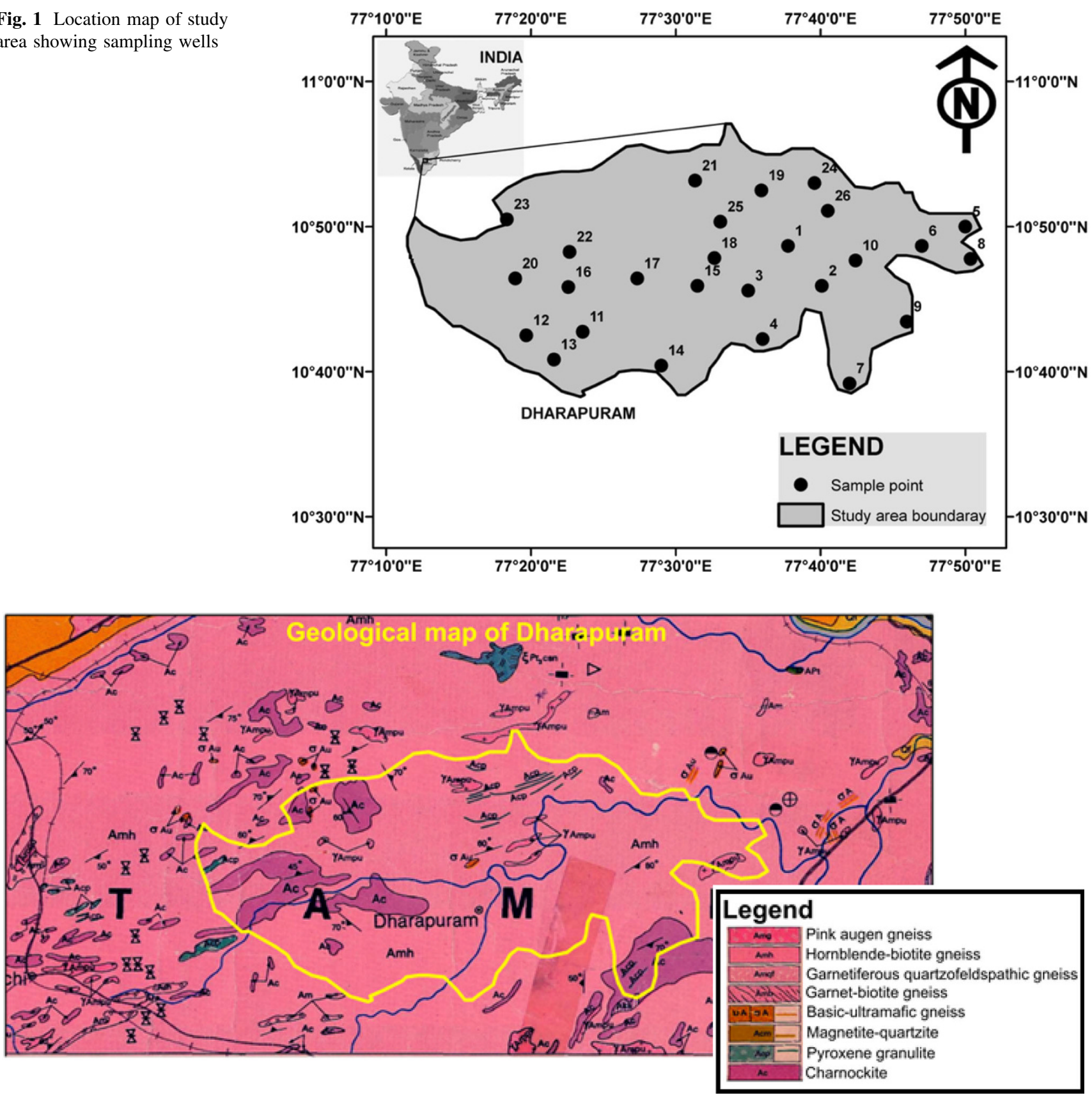

Fig. 2 Geological map of Dharapuram

district, dominant crops such as paddy, maize, cotton, sugarcane and groundnuts are cultivated abundantly. Due to high withdrawal of groundwater, the groundwater table has declined to 50-60 m during the past two decades. So, it is necessary to assess and monitor the groundwater quality and quantity in Dharapuram Taluk.

Groundwater sampling and analytical techniques

A well-designed field survey and groundwater sampling were conducted in the Dharapuram area. Sample locations were located accurately using a geographical information system (GPS). Locations were selected in such a way that the whole area was represented in sampling. A total of 26 groundwater samples were collected during July 2010. The water was pumped out for a fair amount of time prior to the collection of samples. Water samples were collected in polyethylene bottles (1L capacity); the bottles were sealed and brought to the laboratory for analysis and stored at $4{ }^{\circ} \mathrm{C}$ before analysis. Analysis was carried out as per the standard methods suggested by APHA (1995). Only highly pure (AnalR Grade) chemicals and double-distilled water 
Table 1 Hydrochemical parameters in the groundwater of Dharapuram

\begin{tabular}{|c|c|c|c|c|c|c|c|c|c|c|c|c|c|c|}
\hline S. No & $\mathrm{pH}$ & $\mathrm{EC}$ & TDS & $\mathrm{TH}$ & $\mathrm{Ca}^{2+}$ & $\mathrm{Mg}^{2+}$ & $\mathrm{Na}^{+}$ & $\mathrm{K}^{+}$ & $\mathrm{Cl}^{-}$ & $\mathrm{SO}_{4}^{2-}$ & $\mathrm{CO}_{3}^{-}$ & $\mathrm{HCO}_{3}^{-}$ & $\mathrm{NO}_{3}^{-}$ & $\mathrm{F}^{-}$ \\
\hline 1 & 8.4 & 1,020 & 645 & 275 & 34 & 46 & 69 & 82 & 67 & 124 & 24 & 262 & 68 & 1.45 \\
\hline 2 & 8.5 & 1,340 & 747 & 470 & 62 & 77 & 92 & 5 & 174 & 131 & 36 & 281 & 29 & 1.2 \\
\hline 3 & 8.6 & 1,100 & 638 & 265 & 56 & 30 & 74 & 98 & 110 & 37 & 42 & 311 & 35 & 1 \\
\hline 4 & 8.3 & 1,230 & 659 & 360 & 32 & 68 & 115 & 20 & 124 & 10 & 24 & 488 & 101 & 1.36 \\
\hline 5 & 8.2 & 1,190 & 723 & 250 & 34 & 40 & 115 & 98 & 96 & 84 & 18 & 427 & 24 & 1.38 \\
\hline 6 & 8.1 & 1,710 & 1,000 & 630 & 76 & 107 & 115 & 6 & 277 & 192 & 0 & 244 & 105 & 1.46 \\
\hline 7 & 8.1 & 760 & 498 & 285 & 36 & 47 & 46 & 9 & 96 & 26 & 2 & 158 & 94 & 1.07 \\
\hline 8 & 8.3 & 810 & 464 & 290 & 50 & 40 & 46 & 18 & 89 & 72 & 4 & 206 & 21 & 1.12 \\
\hline 9 & 8.2 & 1,020 & 630 & 290 & 48 & 41 & 106 & 9 & 103 & 84 & 0 & 275 & 73 & 1.3 \\
\hline 10 & 8.2 & 1,420 & 767 & 570 & 76 & 92 & 69 & 5 & 177 & 131 & 18 & 348 & 25 & 0.82 \\
\hline 11 & 8.2 & 3,150 & 1,969 & 820 & 128 & 122 & 258 & 176 & 489 & 384 & 0 & 439 & 192 & 0.56 \\
\hline 12 & 8.4 & 2,070 & 1,298 & 640 & 36 & 134 & 175 & 12 & 355 & 110 & 24 & 73 & 415 & 0.88 \\
\hline 13 & 8.3 & 1,200 & 736 & 385 & 54 & 61 & 97 & 20 & 142 & 165 & 12 & 195 & 87 & 1.17 \\
\hline 14 & 8.6 & 680 & 384 & 185 & 24 & 30 & 60 & 20 & 82 & 55 & 6 & 154 & 16 & 1.34 \\
\hline 15 & 8.3 & 1,010 & 550 & 260 & 36 & 41 & 115 & 9 & 163 & 37 & 24 & 226 & 12 & 0.92 \\
\hline 16 & 7.9 & 2,560 & 1,475 & 930 & 160 & 129 & 138 & 30 & 397 & 354 & 0 & 372 & 81 & 1.15 \\
\hline 17 & 8.6 & 1,660 & 970 & 630 & 76 & 107 & 97 & 8 & 234 & 306 & 42 & 140 & 30 & 0.86 \\
\hline 18 & 7.9 & 1,160 & 681 & 365 & 72 & 45 & 60 & 94 & 78 & 62 & 0 & 519 & 10 & 1.35 \\
\hline 19 & 8.7 & 1,100 & 622 & 375 & 36 & 69 & 46 & 82 & 74 & 71 & 54 & 342 & 19 & 1.38 \\
\hline 20 & 8.5 & 3,360 & 2,023 & 900 & 80 & 170 & 276 & 156 & 525 & 264 & 42 & 512 & 254 & 1.46 \\
\hline 21 & 8.3 & 1,740 & 1,019 & 610 & 76 & 102 & 106 & 32 & 284 & 93 & 24 & 220 & 192 & 0.76 \\
\hline 22 & 7.9 & 2,040 & 1,178 & 700 & 160 & 73 & 147 & 11 & 305 & 244 & 0 & 409 & 33 & 1.3 \\
\hline 23 & 8.2 & 2,410 & 1,447 & 640 & 64 & 117 & 253 & 14 & 326 & 477 & 12 & 256 & 56 & 1.3 \\
\hline 24 & 8.9 & 1,160 & 662 & 315 & 22 & 63 & 115 & 21 & 145 & 62 & 60 & 122 & 113 & 1.2 \\
\hline 25 & 8.5 & 1,260 & 740 & 385 & 44 & 67 & 110 & 20 & 145 & 67 & 30 & 293 & 110 & 1.42 \\
\hline 26 & 7.8 & 1,370 & 805 & 235 & 54 & 24 & 207 & 9 & 85 & 39 & 0 & 525 & 124 & 1.48 \\
\hline Min & 7.8 & 680 & 384 & 185 & 22 & 24 & 46 & 5 & 67 & 10 & 0 & 73.2 & 10 & 0.56 \\
\hline Max & 8.9 & 3,360 & 2,023 & 930 & 160 & 170 & 276 & 176 & 525 & 477 & 60 & 525 & 415 & 1.48 \\
\hline Avg & 8.3 & 1,520 & 897 & 464 & 63 & 75 & 120 & 41 & 198 & 142 & 19 & 300 & 89 & 1.18 \\
\hline WHO (2011) & $6.5-8.5$ & - & 1,000 & - & - & 30 & 200 & - & 250 & 200 & - & - & 50 & 1.5 \\
\hline BIS (1992) & & - & 200 & 600 & 75 & & - & - & 250 & 400 & - & - & 45 & $0.6-1.2$ \\
\hline
\end{tabular}

All the ions as well as TDS and TH were measured in $\mathrm{mg} / \mathrm{L}$, while EC was measured in $\mu \mathrm{S} / \mathrm{cm}$ and $\mathrm{pH}$ is unitless

were used for preparing solutions for analysis. EC and $\mathrm{pH}$ were determined in the field using portable digital meters. Calcium $\left(\mathrm{Ca}^{2+}\right)$ and magnesium $\left(\mathrm{Mg}^{2+}\right)$ were determined by titration standard EDTA. Chloride $\left(\mathrm{Cl}^{-}\right)$was determined by standard $\mathrm{AgNO}_{3}$ titration. Carbonate $\left(\mathrm{CO}_{3}^{2-}\right)$ and bicarbonate $\left(\mathrm{HCO}_{3}^{-}\right)$were determined by titration with $\mathrm{HCl}$. Sodium $\left(\mathrm{Na}^{+}\right)$and potassium $\left(\mathrm{K}^{+}\right)$were measured by flame photometry (Deep Vision Digital Flame photometer Model No. 391). Sulphate $\left(\mathrm{SO}_{4}^{2-}\right)$ was determined by using UV-visible spectrophotometer. Nitrate was measured by an ion chromatograph (Metrohm 861 advanced compact IC). The iron balance error (IBE) values were observed to be within the standard limit of $\hat{\mathrm{A}} \pm 5 \%$. The spatial distribution map of nitrate was created using ordinary kriging in the ArcGIS 9.3.

\section{Results and discussion}

General hydro-geochemistry of the study area

The results of analysis of hydrochemical parameters are presented in Table 1. All the water samples were alkaline with a $\mathrm{pH}$ range from 7.8 to 8.9 , with an average of 8.3. Only three samples exceeded the maximum permissible limit of 8.5. The electrical conductivity values ranged between 680 and 3,360 $\mu \mathrm{S} / \mathrm{cm}$, with an average $1,520 \mu \mathrm{S} /$ $\mathrm{cm}$. This wide range of $\mathrm{EC}$, from a more natural level $(680 \mu \mathrm{S} / \mathrm{cm})$ to an elevated level $(3,360 \mu \mathrm{S} / \mathrm{cm}$, probably anthropogenic), is an indication that geogenic and anthropogenic processes are acting on hydrogeochemistry of the study area. Piper trilinear diagram (Piper 1953) suggests 


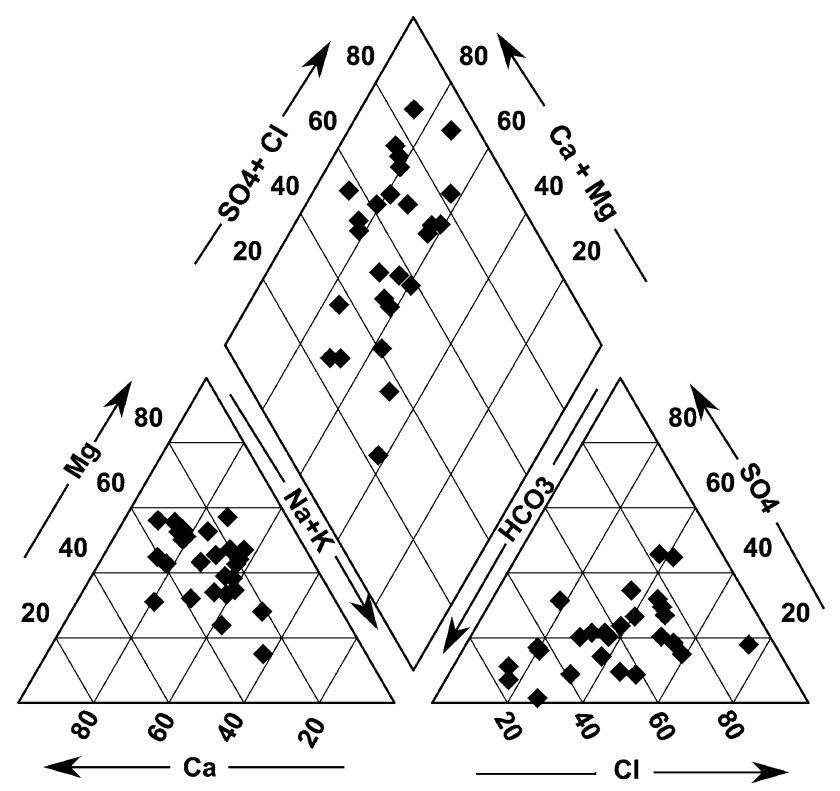

Fig. 3 Piper plot showing the hydrochemical facies in the groundwater of the study area

that there are two major water types, mainly $\mathrm{Ca}-\mathrm{Na}-\mathrm{HCO}_{3}$ and mixed $\mathrm{Ca}-\mathrm{Mg}-\mathrm{Cl}$ prevailing in the groundwater environment (Fig. 3). Considering the geology of the study area, the $\mathrm{Ca}-\mathrm{Na}-\mathrm{HCO}_{3}$ type of water must have originated from the weathering of silicate minerals present in the hard rocks (see the geology map in Fig 2). Though the first hydrochemical facies type represents a more natural origin, the second $(\mathrm{Ca}-\mathrm{Mg}-\mathrm{Cl})$ shows a mixed nature. Since a natural origin of $\mathrm{Cl}$ has not been reported from the study area, this kind of facies represents the anthropogenic influence. This may be noted that there are several textile industries in the study area with a long history of discharging high saline textile wastewater to the water bodies (Geetha et al. 2008). So the high $\mathrm{Cl}$ concentration in groundwater must be sourced from these industries.

Concentration of $\mathrm{Na}^{+}$ranged between 46 and $276 \mathrm{mg} / \mathrm{L}$, while $\mathrm{K}$ ranged from 5 to $176 \mathrm{mg} / \mathrm{L}$. The average concentration of $\mathrm{Na}^{+}$is $120 \mathrm{mg} / \mathrm{L}$, which is far below the suggested limit of $200 \mathrm{mg} / \mathrm{L}$ (WHO 2011). However in few locations, elevated levels of these ions were observed. This result in comparison with the geology suggests an occurrence of rock-water interaction, specifically the weathering of silicate minerals. The average concentration of $\mathrm{Ca}$ and $\mathrm{Mg}$ was 63 and $75 \mathrm{mg} / \mathrm{L}$, respectively. The average concentration of $\mathrm{Cl}(198 \mathrm{mg} / \mathrm{L})$ was below the permissible limit of $200 \mathrm{mg} / \mathrm{L}$. However, a very high concentration of $525 \mathrm{mg} / \mathrm{L}$ was also observed in the study area, probably affected by anthropogenic sources, i.e. textile wastewater. Carbonate was relatively less in concentration in most of the samples, while bicarbonate showed an average concentration of $300 \mathrm{mg} / \mathrm{L}$. Sulphate ranged between 10 and $477 \mathrm{mg} / \mathrm{L}$, with an average of $142 \mathrm{mg} / \mathrm{L}$. The highest concentration of fluoride of $1.48 \mathrm{mg} / \mathrm{L}$ shows that all the water samples are well within the permissible limit of $1.5 \mathrm{mg} / \mathrm{L}$ (WHO 1993).

Spatial distribution of nitrate and its dependency on land use

The concentration of nitrate in the study area ranged from 10 to $415 \mathrm{mg} / \mathrm{L}$. In the present study all samples were compared with both Indian and WHO-recommended limit for $\mathrm{NO}_{3}$ in the drinking water. This analysis shows that $43 \%$ samples satisfied the standard of nitrate, i.e. $45 \mathrm{mg} / \mathrm{L}$ (BIS 1992) and $50 \mathrm{mg} / \mathrm{L}$ (WHO 2011). The alarming fact is that more than $34 \%$ of the samples have a nitrate concentration higher than $100 \mathrm{mg} / \mathrm{L}$. Figure $4 \mathrm{a}$, b illustrates the concentration of $\mathrm{NO}_{3}$ in individual wells and frequency distribution of $\mathrm{NO}_{3}$ concentration, respectively. The spatial distribution of nitrate in the study area (see Fig. 5a) shows that contamination occurs mainly in the SW and NW parts of the study area. However, some of the wells in the NE region are also affected by high nitrate. A comparison of this map with the land-use map (Fig. 5b) shows that SW and NW parts of the study area are mainly agricultural fields. Suthar et al. (2009) reported that the major factors controlling the spatial variation of nitrate are fertilizer application rate, crop rotation, fertilizer utilization efficiency of sown crops, irrigation art, soil texture and local pedo-climatic variability. Farmers in this part of the study use enormous amount of fertilizers to improve their productivity. Cattle farms are always a subsidiary part of agriculture. The wastes from these farms also contribute to the high level of nitrate in the groundwater.

The spatial distribution map shows that there is a great variation in the concentration of $\mathrm{NO}_{3}(5-415 \mathrm{mg} / \mathrm{L})$ from place to place. Water samples of permissible nitrate concentration are observed only in the central part of the study area. Lack of sanitation facilities and increased use of fertilizers also enhanced the level of nitrate in groundwater. A portion of the infiltrated nitrate from these sources is consumed by the plants in the root zone, and the surplus nitrates get leached out through the subsoil to the groundwater reservoirs. This leaching process finally leads to the high concentration of nitrate in the SW and NW parts of Dharapuram.

At this point, it is logical to evaluate the groundwater quality for irrigation in the study area. Since the major focus of this study is on nitrate contamination, a most commonly used irrigation index, Wilcox diagram (after Wilcox 1955), is plotted based on the measured parameters. This plot (Fig. 6) suggests that groundwater is enriched in salinity, but is very low in terms of sodium hazard. 
Fig. 4 a Concentration of $\mathrm{NO}_{3}$ in individual wells. b Frequency distribution of $\mathrm{NO}_{3}$ concentration

Fig. 5 a Spatial distribution of nitrate in groundwater. b Landuse map of Dharapuram

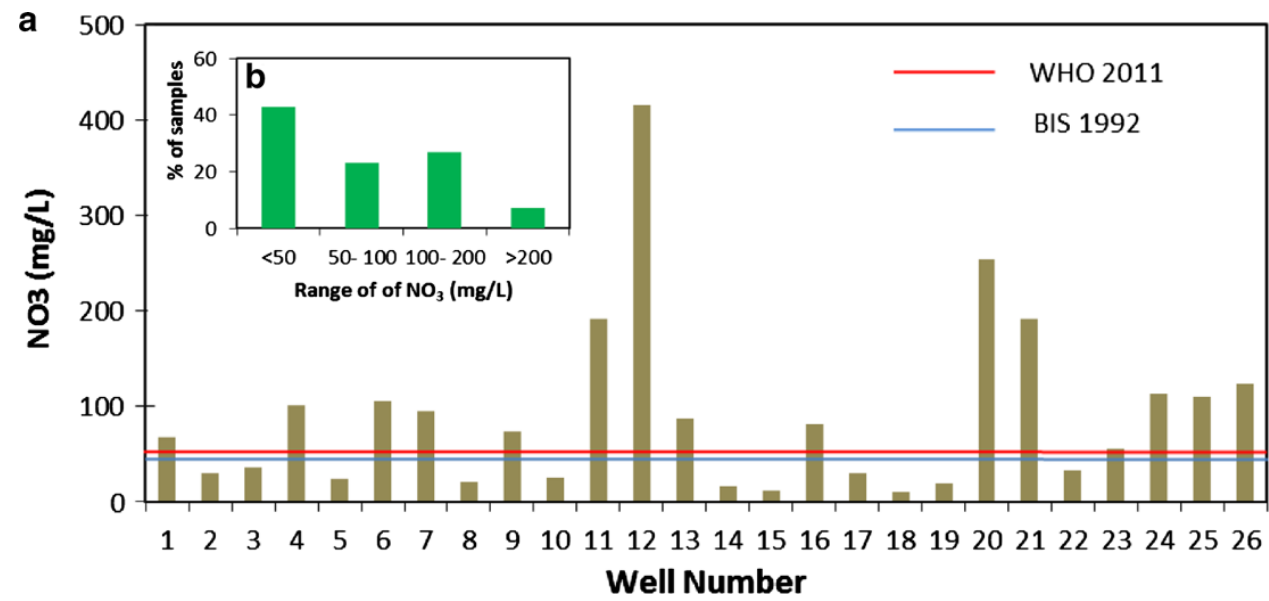

a

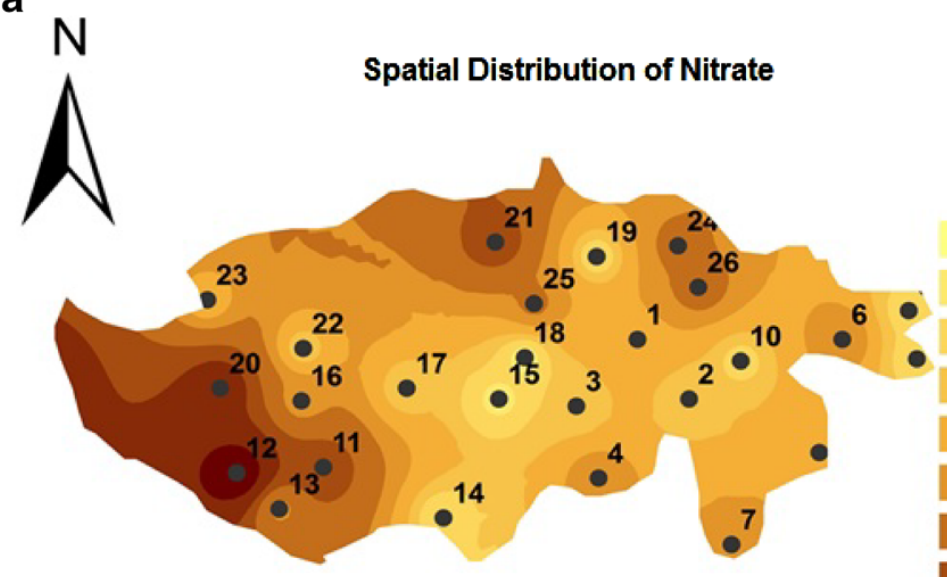

Legend

Nitrate $(\mathrm{mg} / \mathrm{L})$

5 - 10

$10-20$

$20-35$

$35-50$

$50-75$

$75-100$

$100-150$

$150-200$

$200-300$

$300-415$

b

Land Use Map of Dharapuram

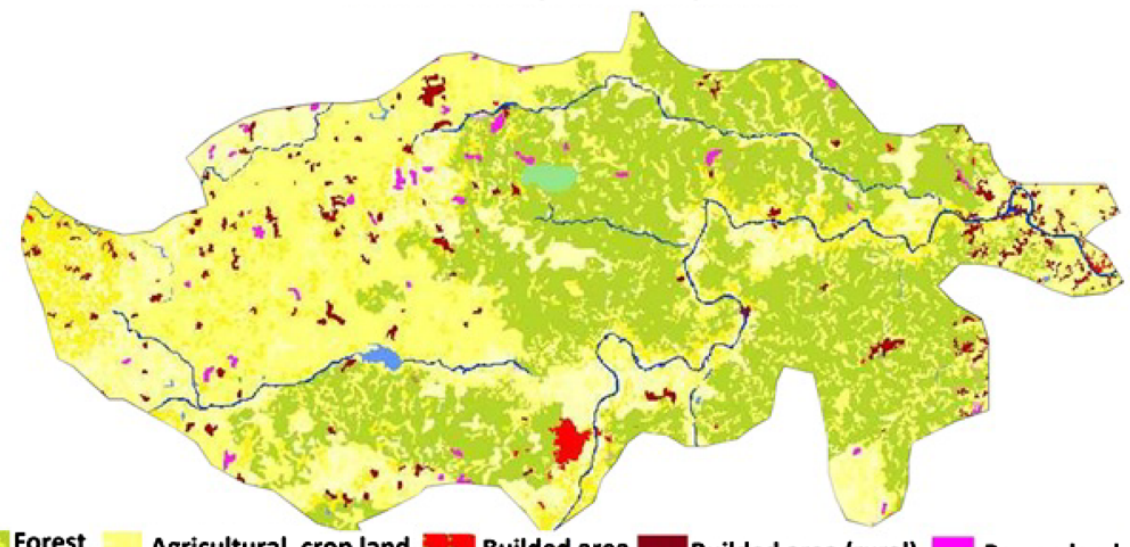

Factors influencing the elevated nitrate concentration in groundwater

Since the main sources of nitrate in the environment are generally from the surface and/or atmosphere, the concentration of $\mathrm{NO}_{3}$ is generally high in the shallow wells. Under reducing condition, the denitrification process takes place and the nitrate is converted into $\mathrm{N}_{2}$. As the depth of well increases, the availability of oxygen is reduced and this results in the lowering of nitrate concentration in groundwater.

In the present study the major factors that may affect the concentration of groundwater such as well depth, $\mathrm{EC}, \mathrm{SO}_{4}$, 


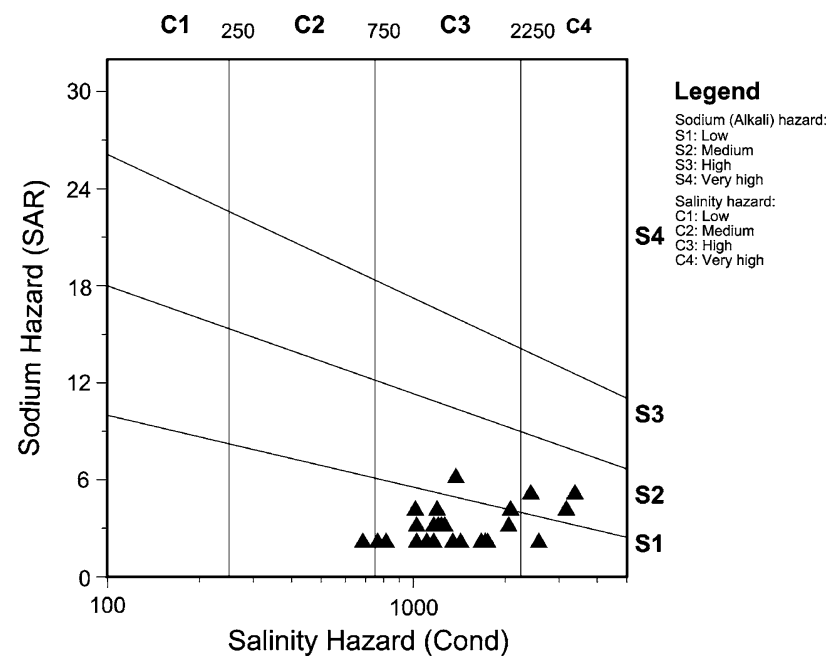

Fig. 6 Wilcox plot showing the utility of groundwater for irrigation in Dharapuram

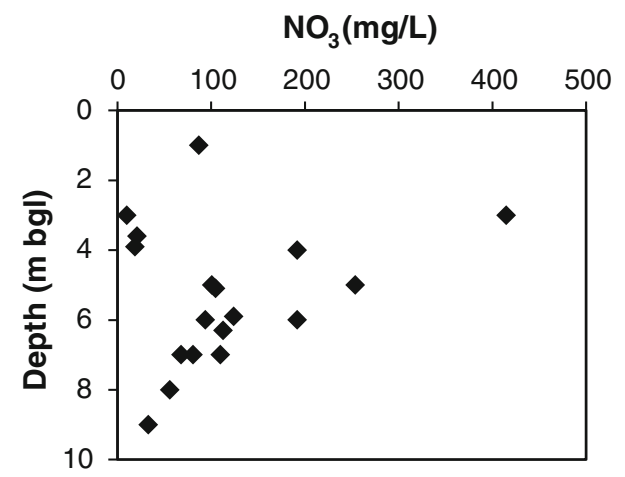

Fig. 7 Bivariate plot showing the relation between well depth and $\mathrm{NO}_{3}$

$\mathrm{Cl}^{-}$and $\mathrm{K}^{+}$were investigated using bivariate plots against $\mathrm{NO}_{3}$. Figure 7 shows the correlation between nitrate and well depth. Most of the samples showed a higher concentration at shallow depths. This may be due to the fact that the main sources of nitrate in the environment are generally from the surface and/or atmosphere, and thus the concentration of $\mathrm{NO}_{3}$ is generally high in shallow wells. In shallow groundwater with abundant oxygen content, the principal source of $\mathrm{NO}_{3}$ is the availability of nitrate for leaching (Reddy et al. 2009). This decreased oxygen content may be the reason for reduced $\mathrm{NO}_{3}$ level in deep groundwater.

EC showed a positive relation with nitrate suggesting that there is an increase in $\mathrm{NO}_{3}$ with an increase in the ionic strength of water (Fig. 8). This shows the common origin of $\mathrm{NO}_{3}$ and some major ions and their contribution to the total ionic strength of groundwater. The important ions that may reach groundwater through the non-point pollution are fertilizers, sewage and animal wastes, chloride and sulphate (Suthar et al. 2009).

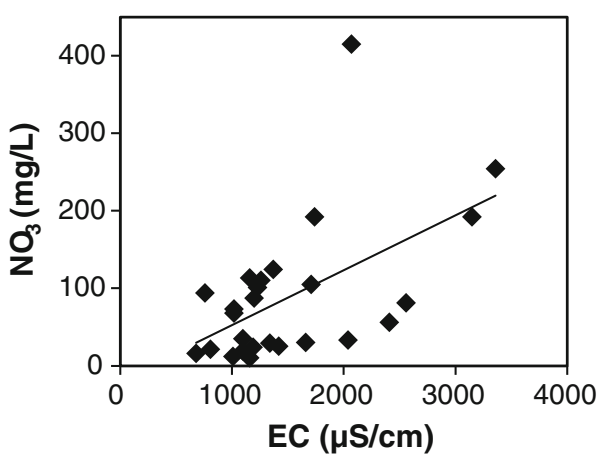

Fig. 8 Bivariate plot showing the relation between $\mathrm{EC}$ and $\mathrm{NO}_{3}$

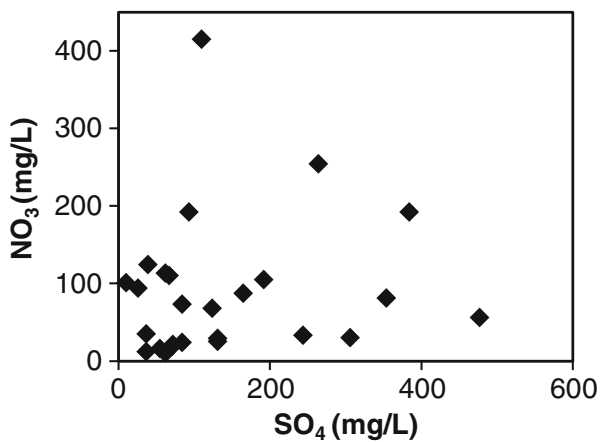

Fig. 9 Bivariate plot showing the relation between $\mathrm{SO}_{4}$ and $\mathrm{NO}_{3}$

Figure 9 indicates that $\mathrm{NO}_{3}$ and $\mathrm{SO}_{4}$ are positively correlated with samples having higher $\mathrm{NO}_{3}$ concentration. Reddy (2013) and Suthar et al. (2009) reported similar results from Andhra Pradesh and Rajasthan, respectively. This result suggests the progressive enrichment of these ions, possibly from the point source pollution. However, at certain locations, sulphate concentration has insignificant correlation with nitrate; these samples have less calcium concentration as well. This may be caused by the precipitation of gypsum $\left(\mathrm{CaSO}_{4}\right)$. The negative correlation between $\mathrm{NO}_{3}$ and $\mathrm{SO}_{4}$ may be attributed to the denitrification process; similar results were obtained by Tang et al. (2004) in their studies in Chibe, Japan.

In certain locations, a good correlation was observed between $\mathrm{NO}_{3}$ and $\mathrm{Cl}$ (Fig. 10). This may be due to the origin of these ions from animal and human wastes. Stigter et al. (1998) also reported a positive correlation between $\mathrm{Cl}$ and $\mathrm{NO}_{3}$, where the pollution sources were agricultural fields. McQuillan (2004) reported that increase in chloride concentration with the increase in nitrate was due to septic tank systems. In the present study, origin may be domestic sewage or agricultural inputs. A strong positive correlation was also observed between $\mathrm{SO}_{4}$ and $\mathrm{Cl}$ (Fig. 11). However, at certain locations, sulphate concentration decreased with increasing $\mathrm{Cl}^{-}$. A similar scenario was observed by Suthar et al. (2009) in Rajasthan, where the major sources of these ions were fertilizers, wastewater and animal excreta. 


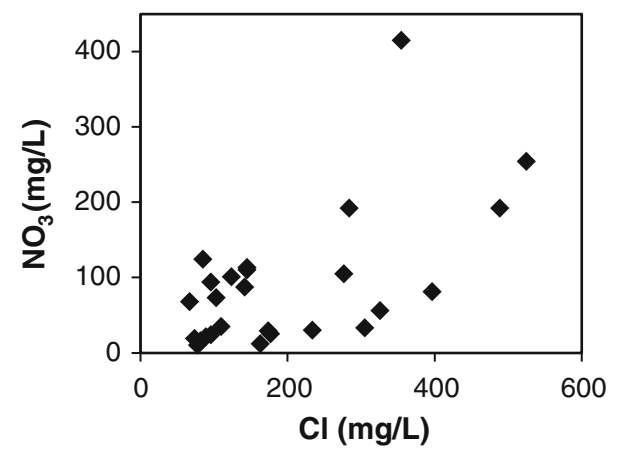

Fig. 10 Bivariate plot showing the relation between $\mathrm{Cl}$ and $\mathrm{NO}_{3}$

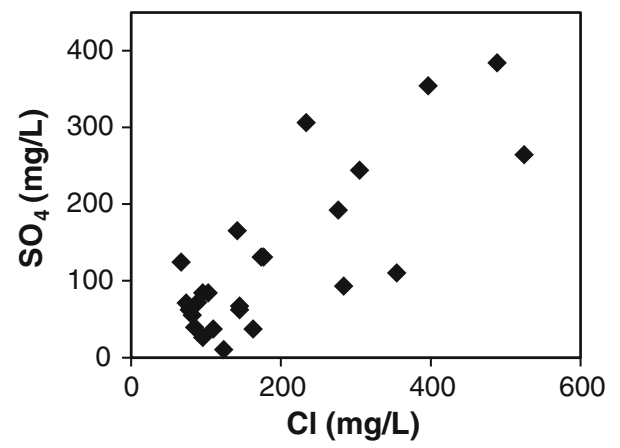

Fig. 11 Bivariate plot showing the relation between $\mathrm{SO}_{4}$ and $\mathrm{Cl}$

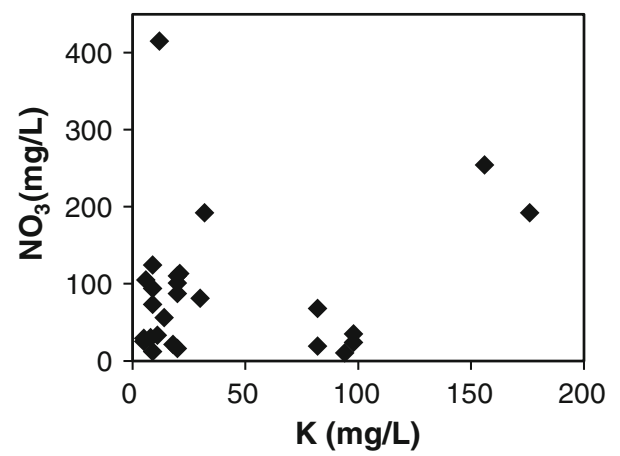

Fig. 12 Bivariate plot showing the relation between $\mathrm{K}$ and $\mathrm{NO}_{3}$

Fertilizers are good sources of $\mathrm{NO}_{3}$ and $\mathrm{K}$ (Fig. 12). There is a positive correlation between these ions in the samples collected from the SW and NW part of the study area. This indicates that the origin of nitrate was from the fertilizers used in agriculture. There are several samples that do not show any relationship with $\mathrm{NO} 3$ and $\mathrm{K}$, confirming their multiple origins other than from fertilizers (Reddy et al. 2009). Few samples showed high concentration of $\mathrm{NO}_{3}$ and low concentration of $\mathrm{K}$. This may be due to the fixation of potassium by the clay minerals. These relations indicate that the major sources of nitrate in groundwater are nonpoint pollution such as fertilizers used for agriculture, open dumping of animal wastes and poor sanitation facilities.

Recommendations for sustainable management of $\mathrm{NO}_{3}-$ contaminated groundwater

1. Future works need to concentrate on vulnerable areas as well as on vertical variations represented in the spatial variation map of nitrate.

2. Detailed studies must be conducted, focusing on pollution sources and modelling of transport mechanisms of nitrate flux, soil characteristics, land-use changes and urbanization.

3. Urban development plans must take precautionary measures to avoid the ill effects of fertilizer applications, industrial effluents and animal wastes on groundwater quality.

4. Cost-effective denitrification processes such as biological treatment methods must be adopted as remedial measures for the existing nitrate contamination problem.

\section{Conclusions}

In this study, we analysed the geochemistry of groundwater with special reference to nitrate concentration in groundwater. Results show that the concentration of $\mathrm{NO}_{3}$ ranged between 10 and $415 \mathrm{mg} / \mathrm{L}$ with an average value of $89 \mathrm{mg} /$ L. In $57 \%$ of the water samples, the nitrate concentration exceeded the permissible limit of drinking, as per Indian and WHO guidelines. Spatial distribution map of $\mathrm{NO}_{3}$ showed that the NW and SW parts were heavily polluted with nitrate. A comparison of land use with spatial variation map of nitrate shows that these areas are intensive agricultural areas. A decreasing trend of $\mathrm{NO}_{3}$ concentration observed with well depth indicated the surficial origin of pollution and the denitrification tendencies at greater depths. A positive correlation of $\mathrm{NO}_{3}$ with $\mathrm{EC}, \mathrm{Cl}, \mathrm{SO}_{4}$ and $\mathrm{K}$ suggests that there is an influence of nonpoint pollution. Fertilizer application and the subsequent leaching of fertilizers are identified as the major causes. However, inefficient sanitation facilities, improper sewage disposal and animal wastes in open places are also factors that influence nitrate concentration in groundwater. More detailed studies using modern tools such as modelling and application of isotopes will be useful for better understanding of the problem.

Open Access This article is distributed under the terms of the Creative Commons Attribution License which permits any use, distribution, and reproduction in any medium, provided the original author(s) and the source are credited. 


\section{References}

Agarwal R (2012) Nitrate contamination in ground water samples of Gangapur city town (Sawai Madhopur District) Rajasthan. J Chem Biol Phys Sci 2(1):511-513

APHA (1995) Standard methods for estimation of water and waste water, 19th edn. American Public Health Association, Washington DC

Arumugam K, Elangovan K (2009) Hydrochemical characteristics and groundwater quality assessment in Tirupur Region, Coimbatore District, Tamil Nadu, India. Environ Geol 58:509-1520

Assaf H, Saadeh M (2009) Geostatistical assessment of groundwater nitrate contamination with reflection on DRASTIC vulnerability assessment: the case of the Upper Litani Basin, Lebanon. Water Resour Manage 23:775-796

Benson VS, VanLeeuwen JA, Stryhn H, Somers GH (2007) Temporal analysis of groundwater nitrate concentrations from wells in Prince Edward Island, Canada: application of a linear mixed effects model. Hydrogeol J 15:1009-1019

BIS (1992) Indian standard specifications for drinking water. BIS: 10500, http://hppcb.gov.in/EIAsorang/Spec.pdf

CGWB (2008) District groundwater brochure Coimbatore district, Tamil Nadu. Technical Report series

Chen S, Wu W, Hu K, Li W (2010) The effects of land use change and irrigation water resource on nitrate contamination in shallow groundwater at county scale. Ecol Complex 7(2):131-138

Cheong J, Hamm S, Lee J, Lee K, Woo N (2011) Groundwater nitrate contamination and risk assessment in an agricultural area, South Korea. Environ Earth Sci 66(4):1127-1136

Comly HH (1987) Cyanosis in infants caused by nitrates in well water. J Am Med Assoc 257:2788-2792

Geetha PN, Palanisamy P, Sivakumar P, Ganesh Kumar M, Sujatha (2008) Assessment of underground water contamination and effect of textile effluents on Noyyal river basin in and around Tiruppur town, Tamilnadu. Chemistry 5:696-705

Hallberg GR (1989) Pesticides pollution of the groundwater in the humid United States. Agric Ecosyst Environ 26:299-367

LWRRDC (1999) Contamination of Australian groundwater systems with nitrate. LWRRDC occasional paper 03/99

Maruyama T, Noto F, Takimoto H, Nakamura K, Yoshida M, Onishi $\mathrm{T}$, Kawasima S (2011) Assessment of long-term changes in nitrogen pollution load potential from sewage treatment water in the Tedori River Alluvial Fan Area, Japan. Paddy Water Environ, 9:451-459

McQuillan D (2004) Ground-water quality impacts from on-site septic systems. Proceedings, National Onsite Wastewater Recycling Association, 13th annual conference, Albuquerque, NM, 7-10 Nov, pp 13

Melo A, Pinto E, Aguiar A, Mansilha C, Pinho O, Ferreira IMPLVO (2011) Impact of intensive horticulture practices on groundwater content of nitrates, sodium, potassium, and pesticides. Environ Monit Assess 184(7):4539-4551

Mishima Y, Takada M, Kitagawa R (2011) Evaluation of intrinsic vulnerability to nitrate contamination of groundwater: appropriate fertilizer application management. Environ Earth Sci 63: $571-580$
Mondal NC, Saxena VK, Singh VS (2008) Occurrence of elevated nitrate in groundwaters of Krishna delta, India. Afr J Environ Sci Technol 2(9):265-271

Murgulet D, Tick GR (2009) Assessing the extent and sources of nitrate contamination in the aquifer system of southern Baldwin County, Alabama. Environ Geol 58:1051-1065

Nas B, Berktay A (2006) Groundwater contamination by nitrates in the city of Konya (Turkey): a GIS perspective. J Environ Manage 79(1):30-37

Piper AM (1953) A graphic procedure in the geochemical interpretation of water analysis. Trans. US Geol Surv Groundwater Notes 12

Rao NS (2006) Nitrate pollution and its distribution in the groundwater of Srikakulam district, Andhra Pradesh, India. Environ Geol 51:631-645

Reddy AGS (2013) Geochemical evaluation of nitrate and fluoride contamination in varied hydrogeological environs of Prakasam district, southern India. Environ Earth Sci. doi:10.1007/s12665013-2841-x

Reddy AGS, Kumar KN, Rao DS, Rao SS (2009) Assessment of nitrate contamination due to groundwater pollution in north eastern part of Anantapur District, A.P, India. Environ Monit Assess 148:463-476

Spalding RF, Exner ME (1993) Occurrence of nitrate in groundwater-a review. J Environ Quality 22:392-402

Stigter TY, van Ooijen SPJ, Post VEA, CAJ Appelo, Carvalho AMMD (1998) A hydrogeological and hydrochemical explanation of the groundwater composition under irrigated land in a Mediterranean environment, Algarve, Portugal. J Hydrol 208:262-279

Suthar S, Bishnoi P, Singh S, Mutiyar PK, Nema AK, Patil NS (2009) Nitrate contamination in groundwater of some rural areas of Rajasthan, India. J Hazard Mater 171:189-199

Tang C, Azuma K, Iwami Y, Ohji B, Sakura Y (2004) Nitrate behaviour in the groundwater of a headwater wetland, Chiba, Japan. Hydrol Process 18:3159-3168

Townsend MA, Young DP (2000) Assessment of nitrate-nitrogen distribution in Kansas groundwater, 1990-1998. Natural Resour Res 9:125-134

Wakida FD, Lerner DN (2005) Non-agriculture sources of groundwater nitrogen: a review and case study. Water Res 39:3-16

Ward MH, de Kok TM, Levallois P, Brender J, Gulis G, Nolan BT, Van Derslice J (2005) Workgroup report: drinking-water nitrate and health-recent findings and research needs. Environ Health Perspect 113:1607-1614

WHO (1993) Guidelines for drinking-water quality. Health criteria and other supporting information, Vol 2 and Drinking water quality control in small community supplies, Vol 3

WHO (2011) Guidelines for drinking-water quality, 4th edn. World Health Organ, Geneva

Wick K, Heumesser C, Schmid E (2012) Groundwater nitrate contamination: factors and indicators. $\mathrm{J}$ Environ Manage 111(30): $178-186$

Wilcox LV (1955) Classification and use of irrigation water. US Department of Agriculture, Circ. 696, Washington DC 